\title{
A linguagem em círculos: experiência e narração em Ricardo Piglia
}

Rafaela Scardino ${ }^{a}$

Alexandre Jairo Marinho Moraes ${ }^{b}$

\begin{abstract}
Resumo
Um dos relatos da máquina do romance A cidade ausente, do escritor argentino Ricardo Piglia, apresenta a história de uma menina que, buscando reservar "para si um território próprio [...] do qual quer excluir toda experiência", acaba por eliminar, desse modo, a linguagem. Assim, sem constituir experiências com as palavras, a menina não apaga apenas o outro, mas também a si mesma, de um relacionamento com o mundo. Como narrar não é exatamente compreender, a experiência constitui-se, fundamentalmente, nas lacunas do que se relata. É na falha, na cisão entre saber e não saber, que se dá, portanto, a narração. A experiência e a narrativa instauram-se nesse intervalo, que se abre, necessariamente, para o outro. A partir de considerações sobre a transmissão da experiência na contemporaneidade, buscamos analisar de que forma, na obra pigliana, acontece a relação entre linguagem e experiência.
\end{abstract}

Palavras-chave: Experiência, Linguagem, Ricardo Piglia.

Recebido em 26 de maio de 2015 Aceito em 27 de agosto de 2015

\footnotetext{
a Doutoranda do Programa de Pós-Graduação em Letras/UFES, rafaelascardino@yahoo.com.br.

b Doutor em Letras (Ciência da Literatura) pela UFRJ. Professor do Programa de Pós-Graduação em Letras/UFES, alexjmm@gmail.com.
} 
A experiência constitui-se no momento de sua transmissão, ou seja, no seu deslocamento. Walter Benjamin (1994), em seu conhecido ensaio sobre o narrador, destaca o progressivo desaparecimento dessa figura, que identifica como fundamental para a transmissão da experiência - é preciso entender esse narrador como aquele da tradição oral, e não o que está presente em narrativas literárias. O narrador tradicional fala a partir de experiências que ele mesmo viveu ou que lhe foram transmitidas de fonte direta, imediata; poderíamos aproximar seu método narrativo daquele de Heródoto, como nos diz Jeanne-Marie Gagnebin.

O nascimento da História, na Grécia, está ligado à instância da verdade do discurso e, para tanto, é fundamental a presença do outro, que comparece, muitas vezes, como testemunha. Gagnebin afirma que

Heródoto fala daquilo que ele mesmo viu, ou daquilo de que ouviu falar por outros; ele privilegia a palavra da testemunha, a sua própria ou a de outrem. Inúmeras vezes, no decorrer de sua narrativa, o nosso viajante menciona as suas "fontes", se ele mesmo viu o que conta ou se só ouviu falar e, neste caso, se o "informante" tinha visto, ele mesmo, ou só ouvido falar (GAGNEBIN, 1997, p. 16).

Vemos que, também no texto de Heródoto, conforme a citação acima, o relato nasce da possibilidade de experiência: do próprio sujeito que narra, ou de outro. Ou ainda da experiência transmitida pela fala, por ouvir contar (narrar) alguém que a tivesse acumulado. Cabe destacar que a palavra história deriva do grego histor, termo que remete à visão e ao testemunho (Cf. GANGEBIN, 1997, p. 16; AGAMBEN, 2005, p. 14). A especificidade das narrativas de Heródoto reside no processo de sua formulação, sempre dependente da experiência transmitida.

Maria Rita Kehl ressalta a necessidade do outro para a constituição da experiência ao afirmar que "a experiência não se constitui no momento em que se vive um episódio qualquer: ela ganha sentido no après-coup, ao ser relatada a alguém. A transmissão permite ao sujeito apossar-se do vivido e extrair dele um saber comunicável" (KEHL, 2009, p. 224). Assim, a experiência se constitui no processo de deslocamento, no ato 
${ }^{1}$ Sobre Erfahrung e Erlebnis, escreve Leandro Konder: "Erfahrung é o conhecimento obtido através da experiência que se acumula, que se prolonga, que se desdobra, como numa viagem; o sujeito integrado numa comunidade dispõe de critérios que lhe permitem ir sedimentando as coisas com o tempo. Erlebnis é a vivência do indivíduo privado, isolado, é a impressão forte, que precisa ser assimilada às pressas, que produz efeitos imediatos". Apud BENJAMIN, W. "Sobre alguns temas em Baudelaire", op. cit., p. 146 n. narrativo/enunciativo que não se pode dar fora de uma relação com o outro. Por isso é tão importante o caráter coletivo da narração ligada à experiência: a inserção do outro no discurso permite a criação de laços subjetivos, de uma comunidade, poderíamos dizer. Kehl cita, ainda, a definição de Shoshana Felman para o testemunho: "testemunhar é tentar produzir significação para uma catástrofe" (in COSTA, 2001, p. 19). A literatura coloca-se, ao levar a língua a seu limite e buscar dizer o irrepresentável, na posição do testemunho, buscando criar significação para aquilo que, de certa forma, se coloca para além da linguagem, abrindo-se sempre para o outro, instaurando o círculo enunciativo característico aos atos discursivos, em que a enunciação de um eu sempre pressupõe um tu (cf. BENVENISTE, 1989). Neste encontro entre sujeitos cria-se um possível saber que não pode ser dissociado da experiência. Assim, retomamos Maria Rita Kehl, quem afirma que não é possível, portanto, dissociar experiência e testemunho, pois "é no ato de testemunhar, ou de narrar, ato de fala endereçado a um outro, que o vivido se constitui como experiência" (in COSTA, 2001, p. 22).

Walter Benjamin estabelece distinções entre duas configurações das experiências vividas: Erfahrung, a experiência tradicional, coletiva, e Erlebnis, experiência individual, característica de sujeitos solitários, comumente traduzida por "vivência"1. Em uma interpretação de origem psicanalítica sobre o conceito de experiência na obra do filósofo alemão, Maria Rita Kehl define a Erlebnis como aquela vivência que "produz sensações e reações imediatas mas não modifica necessariamente o psiquismo" (KEHL, 2009, p. 160). Muitas de nossas atividades cotidianas necessitam do automatismo conferido pela Erlebnis para a preservação psíquica dos sujeitos, mas sua predominância, em detrimento da Erfahrung, acaba por gerar uma sensação de esvaziamento subjetivo.

Quanto à Erfahrung, termo comumente traduzido apenas como experiência, interessa-nos destacar sua proximidade etimológica com o verbo alemão fahren, que designa, dentre outras acepções, o ato de deslocar-se. Assim, a experiência possuiria em sua própria composição a noção de ir em direção a algo, ou a algum lugar, tratando-se, aqui, de um outro sujeito, com o qual, na narrativa, constituir experiência. Destacamos, também, o caráter público da experiência, pois é na coletividade 
que se efetiva sua constituição/transmissão, em uma vocação ética de cuidado com o outro.

Outra distinção que se apresenta é a que existe entre o narrador tradicional, descrito por Benjamin, e o autor, especificamente o autor de romances - forma moderna e fortemente ligada a uma tradição burguesa, enquanto o narrador tradicional faria parte das camadas populares. As experiências e o saber que compõem a narrativa tradicional são parte de sua organização comunitária; não se pode concebêlo fora de sua inserção na coletividade. A experiência da autoria tampouco exclui o outro, mas não se pode afirmar que pertença à coletividade, pois não podemos ignorar a função de delimitação e de autoridade exercida pelo nome do autor em nossa sociedade (Cf. FOUCAULT, 2001). No romance $A$ cidade ausente, de Ricardo Piglia (1997), encontramos uma máquina geradora de relatos que não pode se encaixar seja na noção tradicional de narrador seja na moderna concepção de autoria, sendo descrita como repositório de memória coletiva. E, em um movimento que a aproximaria, de certa forma, das narrativas tradicionais descritas por Benjamin, seus relatos são lacunares, não buscam informar nem explicar, mas, antes, situam-se na cisão entre o dizer e o informar.

Em "Sobre alguns temas em Baudelaire", Benjamin afirma que a narrativa "não tem a pretensão de transmitir um acontecimento pura e simplesmente (como a informação o faz); integra-o à vida do narrador, para passá-lo aos ouvintes como experiência" (BENJAMIN, 1989, p. 107). Nesse sentido, os relatos da máquina aproximam-se das narrativas tradicionais, pois "[a]s imprecisões formavam parte da construção da história. Não era possível ajustá-la a um tempo fixo e o espaço era indeciso [...]" (PIGLIA, 1997, p. 84).

Narrar é, de certa forma, construir uma comunidade entre aquele que narra e seus ouvintes, mas também entre os ouvintes mesmos. A própria circulação dos relatos da máquina, no romance de Piglia, estabelece lugares na cidade - em geral, rotas sub-reptícias - onde sujeitos que nunca se encontraram podem reconhecer-se uns nos outros, partilhando do saber que emerge dos relatos. A máquina não pode deixar de falar - "estou cheia de histórias, não posso parar" (PIGLIA, 1997, p. 137) -, está condenada a ser construtora de memórias, a memória coletiva, por isso interminável. Afirmando seu 
compromisso - que caracterizamos como ético - com a narrativa (e a experiência), a máquina estaria ligada à origem da linguagem, devendo ser, também, repositório das experiências de linguagem e, portanto, das experiências que constituem, de forma basilar, os sujeitos:

as formas estão ali, as formas da vida, eu as vi e agora elas saem de mim, extraio os acontecimentos da memória viva, a luz do real treme, fraca, sou a cantora, aquela que canta, estou na areia, perto da baía, no fio da água posso ainda recordar as velhas vozes perdidas, estou só ao sol, ninguém se aproxima, ninguém vem, mas eu vou seguir, adiante está o deserto, o sol calcina as pedras, eu me arrasto às vezes, mas vou seguir, até a beira da água, sim (PIGLIA, 1997, p. 137).

A ausência de explicação das narrativas tradicionais é, também, uma cisão entre a possibilidade e a impossibilidade de dizer. É a manutenção do narrar em sua potência, mas também em sua impotência: o silêncio.

Como se continuar a transmitir aquém de toda explicação, continuar a falar mesmo sem saber se, um dia, alguém ouvirá, como se essa absurda e última aposta na linguagem e na comunicação desenhasse ainda a figura frágil de uma possível humanidade. Renunciar a contar e a transmitir, mesmo por falta de palavras ou por excesso de dor, significaria, de uma certa maneira e sem querê-lo, pactuar com a ignomínia. Há, portanto, que obrigar-se a falar e a escrever (GAGNEBIN, 2009, p. 109).

E assim, atendendo ao chamado ético da fala, da narrativa, a máquina não pode deixar de gerar seus relatos, ainda que estejam sujeitos à perseguição e a ações que buscam seu apagamento.

Em A cidade ausente, Junior, o jornalista encarregado de contar a história da máquina, vai ao encontro de Russo, um de seus criadores, quem lhe afirma sobre as narrativas: "Sempre começa assim, o narrador está sentado como eu, numa poltrona de vime, ele se balança, de cara para o rio que corre, sempre foi assim, desde o início, há alguém do outro lado que espera, que quer ver como continua" (PIGLIA, 1997, p. 119). Dessa forma, verificamos que a importância da figura de um narrador para a constituição e transmissão da experiência é uma forma de 
afirmar que esta não se dá fora da palavra, mas, acrescentamos, precisa também do corpo. Assim como a experiência se efetiva em sua transmissão, a fala também cria o corpo, e o domínio do corpo cria experiência: "O sentido amplo da experiência inclui o corpo na relação com o semelhante e com o real (como uma determinada produção de ato do sujeito)" (COSTA, 2001, p. 132). O corpo desmoralizado não pode inserir-se na produção coletiva de experiências, pois perde a borda ética do contato com outro, suas vivências não lhe permitem o estabelecimento de uma comunidade onde se dá a transmissão em sua forma tradicional. Em "Prisão perpétua", o tema da constituição de experiências é colocado lado a lado com a desmoralização do corpo encarcerado. Vejamos o texto:

A prisão deve ser vista como um laboratório. Realizam-se com homens e mulheres experiências muito sofisticadas. Procuram-se reconstruir artificialmente as condições da vida futura. Observa-se como reage um indivíduo quando é totalmente privado de experiências durante um longo tempo (PIGLIA, 1989, p. 23).

Neste trecho, vemos pessoas, homens e mulheres, de quem é retirada certa parte da experiência, pois não podem mais colocar-se na posição de sujeito e são objetos de experimentos conduzidos por um poder centralizador e desmoralizante, como acontece em A cidade ausente, obra em que o poder estatal opressor se insinua nas vidas e nos relatos dos personagens. Como um exemplo dessa insinuação, podemos citar a personagem Julia Gandini, uma possível informante de Junior, que é na verdade uma "arrependida" - suas experiências na luta contra a repressão são sufocadas e substituídas por outras (imaginárias), condizentes com o discurso oficial: "Repetia a lição como um papagaio, num tom tão neutro que parecia irônico. Era uma arrependida. Tinha participado dos grupos de autoajuda e não se podia saber se era sincera ou se estava esquizofrênica" (PIGLIA, 1997, p. 75-76). “O cárcere”, escreve Isabel Quintana sobre a obra de Piglia, "se converte na alegoria do fim da experiência comunitária" (QUINTANA, 2001, p. 86). $\mathrm{O}$ encarceramento reduz a experiência ao corpo, com o qual havemos sempre de estar às voltas, mas, em sua desmoralização, exclui a comunidade e, consequentemente, a possibilidade de 
transmissão. Tais personagens estão excluídos das formas tradicionais de transmissão da experiência, e perderam a capacidade de narrar. Pois existe uma associação entre a constituição da experiência e a dignidade, uma proposta ética: é apenas em uma relação ética consigo mesmo, com o outro e com o mundo que o sujeito pode constituir experiência.

\section{Recusa à experiência}

Em nossos dias, não são apenas figurações da transmissão de experiências, como o narrador tradicional, que se encontram em vias de extinção, mas também pessoas ávidas por experimentar o mundo. Como exemplo desta possível "recusa à experiência", podemos citar as massas de turistas que relegam à câmara fotográfica a visão dos locais visitados, ou pessoas que têm relacionamentos puramente virtuais (e superficiais), sem arriscar-se ao contato com o outro.

A respeito do intrigante e cada vez mais comum hábito de se relegar à máquina fotográfica (ou a qualquer outro dispositivo com tal função, como o telefone celular) o contato com belas paisagens, pontos turísticos ou obras de arte, cabe comentar projetos de intervenção artístico-social como Photoland, do brasileiro Fábio Seixo (cf. GOMBATA, 2013), ou Too much photography, do inglês Martin Parr. Seixo e Parr são fotógrafos profissionais que têm projetos similares: o de fotografar pessoas fotografando(-se) em espaços icônicos, como os já citados pontos turísticos. Parr, fotógrafo experiente da agência Magnum, escreve em seu site que vem se tornando cada vez mais difícil fotografar lugares turísticos sem que as pessoas que visitam tais lugares sejam capturadas tirando fotografias elas mesmas.

Viaja-se, muitas vezes, para ver o já visto, seja através de filmes, guias turísticos, material publicitário ou outros. A circulação, em especial nos destinos turísticos mais tradicionais, relaciona-se a uma movimentação que se pretende docilizada, livre do choque e do inesperado: a vivência do novo não é rejeitada, mas esse novo deve vir precedido de alguma informação que amorteça as surpresas. Outro dado importante é a demarcação do espaço pela presença do eu. Registrar fotograficamente, especialmente quando essa fotografia inclui o turista, é uma forma de documentar a presença nesse espaço 
algo mítico, porque tão anunciado e desejado. É como registrar o satisfazer-se de um desejo, mas sabemos que o desejo está sempre no mais além de sua satisfação. Esse estar presente, no entanto, não pressupõe o ver: abarcar com os olhos, tomar para si o espaço visitado, essa operação eminentemente subjetiva fica de fora do viajar, é preciso registrar fotograficamente uma presença que não se efetiva subjetivamente.

O grande número de fotografias aponta, ainda, para outra questão: busca-se registrar o momento de modo que se possa exibi-lo (para um terceiro ou para uma versão futura de nós mesmos) em uma versão ideal, pois são deletadas as fotos que não correspondem à noção idealizada do evento. Maria Rita Kehl também associa o afã fotográfico ao empobrecimento da experiência proposto por Benjamin, questionando se não

[s]eria essa necessidade de registrar em imagens supostamente fidedignas cada momento vivido um sintoma de que a temporalidade socialmente regulada na vida contemporânea esteja encurtando a experiência subjetiva da duração? Um dos efeitos dessubjetivantes da velocidade é o empobrecimento da imaginação: o que se busca, no instantâneo fotográfico, é uma espécie de atestado de que a vida [...] tenha sido de fato vivida (KEHL, 2009, p. 189).

Mas esta recusa à experiência pode, no entanto, apontar para algo propositivo, pois, como afirma Agamben, "talvez se esconda, no fundo desta recusa aparentemente disparatada, um grão de sabedoria no qual podemos adivinhar, em hibernação, o germe de uma experiência futura" (AGAMBEN, 2005, p. 23), ou seja, uma forma de resistência: "quando a única experiência possível é, portanto, o horror, e a mentira, nesta circunstância uma recusa da experiência pode - provisoriamente - constituir uma defesa legítima" (AGAMBEN, 2005, p. 24, grifos nossos). A obra de Piglia se insere nesta possibilidade propositiva, pois busca uma nova forma de narrar a experiência, colocandose no lugar daquele sujeito que, para se defender, deve falar (testemunhar), deslocando o discurso oficial (do horror, da violência supostamente necessária). Transferir a experiência à máquina - semeando, assim, o "germe da experiência futura" - é afirmar o lugar da literatura como produtora de experiência, em especial, daquilo a que Benjamin se refere como experiência ética. 
Socialmente, no entanto, encontramos algo que poderíamos chamar de busca por "experiências domesticadas", que não provocam modificação significativa em quem delas toma parte, mantendo inalterada a ordem das coisas, sem deslocá-las. Isto, a que chamamos experiência por um alargamento no uso do vocábulo, toma parte da desmoralização apontada por Benjamin e pode ser aproximada da Chockerlebnis, a vivência do choque, analisada pelo filósofo alemão. Benjamin afirma que, na modernidade, a vivência do choque tornou-se regra. Recorrendo aos estudos freudianos, assim descreve tal fenômeno:

A recepção do choque é atenuada por meio de um treinamento no controle dos estímulos, para o qual tanto o sonho quanto a lembrança podem ser empregados, em caso de necessidade. Via de regra, no entanto, este treinamento [...] cabe ao consciente desperto [...]. O fato de o choque ser assim amortecido e aparado pelo consciente emprestaria ao evento que o provoca o caráter de experiência vivida em sentido restrito. E, incorporando imediatamente este evento ao acervo das lembranças conscientes, o tornaria estéril para a experiência poética (BENJAMIN, 1989, p. 110).

A respeito deste texto, a psicanalista Maria Rita Kehl escreve que

[a] exigência contínua e veloz que a máquina impõe ao homem convoca permanentemente a atenção consciente dos habitantes das grandes cidades ao trabalho de amparar os choques advindos de todas as outras dimensões da vida urbana. A mobilização contínua da atenção consciente chega a impedir outras formas de percepção e fruição da temporalidade, entre as quais aquelas que fornecem a matéria da experiência - seja poética, literária ou narrativa, isto é: transmissível (KEHL, 2009, p. 182).

Assim, podemos dizer que a vivência do choque domestica a sensibilidade, o que implicará na diminuição das atitudes de efetivo contato com o outro. Tal característica é especialmente forte nas metrópoles, sendo uma de suas formas a "atitude blasé" estudada por Georg Simmel. Segundo o sociólogo, a atitude blasé seria fruto do excesso de estímulos que vivem os habitantes das grandes cidades. Tal atitude consistiria 
em um embotamento da sensibilidade, decorrendo disso que "o significado e valores diferenciais das coisas, e daí as próprias coisas, são experimentados como destituídos de substância" (SIMMEL, 1979, p. 16). Esse comportamento adquire, na contemporaneidade, contornos do que Richard Sennett definiu com um apassivamento dos sujeitos contemporâneos, que encontra eco na forma como estão organizadas nossas cidades (e, de forma mais ampla, os espaços urbanizados de circulação, como a malha rodoviária). Nossas cidades cada vez mais inchadas devem seu desenho às metrópoles de começos do século XX analisadas por Simmel. Em nossos tempos, no entanto, acentuam-se mecanismos espaciais de individualização e distanciamento entre pessoas que circulam por um mesmo espaço. Tal espaço encontra-se, muitas vezes, fragmentado e seccionalizado, organizado de tal forma que se possa circular por ele sem entraves à movimentação.

A essa organização espacial, ligam-se formas de olhar: domesticamos nosso olhar para o espaço e, através das tecnologias de imagem, domesticamos nosso olhar também para as relações de alteridade. A avalanche de imagens e informações a que estamos submetidos são, em diversos meios de comunicação de massas, apresentadas de maneira a provocar o choque. Mas nossa psique, como vimos, vem desenvolvendo métodos de lidar com tais experiências, decorrendo disso um olhar que não se permite abalar por (todas) as imagens de violência e dor. Precisamos da Chockerlebnis, da atitude blasé e do apassivamento, também, como formas de proteção. O problema se coloca quando precisamos acionar tais mecanismos de proteção a todo momento, embotando nossa capacidade de discernir as situações em que o abrir-se para o outro - e para a dor, inclusive - seria fundamental não somente para a constituição efetiva da experiência, mas também para a constituição de nossa própria humanidade. Sobre isso, escreve Sennett:

Ambos, o engenheiro civil e o diretor de televisão, criam o que se pode chamar de "liberdade da resistência". Enquanto um projeta caminhos por onde o movimento se realize sem obstruções ou maiores esforços, e com a menor atenção possível aos lugares de passagem, o outro explora meios que permitem às pessoas olhar para o que quer seja, sem desconforto (SENNETT, 1997, p. 18). 
Uma outra forma de pensar essa proteção gerada pela dupla vivência/experiência, é afirmada por Giorgio Agamben: "[a] experiência é, de fato, voltada primeiramente à proteção contra as surpresas, e o produzir-se de um choque implica sempre em uma brecha na experiência. Fazer experiência de alguma coisa significa: subtrair-lhe a sua novidade, neutralizar o seu poder de choque" (AGAMBEN, 2005, p. 52). Tais palavras nos levam a pensar nas "redes de proteção" que se estabelecem em cidades pequenas, nas quais os estímulos são mais reduzidos e vive-se em ambiente relativamente controlado, em que o novo - o choque causado pelo novo - é amortecido. As cidades pequenas são, em suas formas tradicionais, mais propícias àquela figura denominada por Walter Benjamin de narrador (como o camponês e o artesão), pois estão menos sujeitas à seccionalidade de espaços e, por conseguinte, à evasão do encontro com o outro, sendo, dessa forma, territórios mais favoráveis ao estabelecimento de comunidades efetivas. As metrópoles, por sua vez, caracterizam-se como o espaço por excelência da informação e do choque.

Nossa vida dominada pelas práticas culturais irradiadas pelas grandes aglomerações urbanas, atingindo a vida em cidades menores e provocando mudanças em sua organização, fomenta aquilo que chamamos de "experiências domesticadas". Um exemplo interessante é o consumo de alimentos industrializados. Em matéria republicada na seção de Gastronomia do jornal brasileiro Valor Econômico, a jornalista Miriam Gottfried, do Wall Street Journal, informa sobre os novos sabores criados pela indústria norte-americana de alimentos. São descritos sabores desenvolvidos em laboratórios por grandes empresas que buscam conquistar cada vez mais consumidores interessados em novas vivências do paladar: "Os salgadinhos ficaram mais apimentados. O chiclete ficou mais mentolado. As bebidas energéticas estão mais frutadas. Resumindo, a cozinha americana ganhou um pouco de adrenalina" (GOTTFRIED, 2010, p. 29), assim sintetiza a jornalista a elaboração do que chama de sabores, ainda na introdução de seu artigo. O que se busca proporcionar aos consumidores "não é exatamente um sabor, dizem executivos do setor alimentício, mas uma experiência - uma explosão de sabor" (GOTTFRIED, 2010, p. 29). 
Tais sabores "turbinados" são apresentados como alternativa à mesmice da tradicional culinária norte-americana, conhecida "pelo purê de batata, pelos espetinhos de frango, o macarrão com queijo e outros pratos pouco empolgantes" (GOTTFRIED, 2010, p. 29). Dessa forma, os alimentos naturais seriam substituídos por alimentos industrializados, com novos sabores a cada momento, cada vez mais intensos (assim são divulgados) e menos sutis - e também menos diferenciados. Citamos ainda a reportagem:

Como a tendência é buscar sabor intenso, alguns tradicionalistas se perguntam se as pessoas ficarão insensíveis aos sabores naturais. A manga normal pode parecer insípida quando consumida depois de um chiclete ou uma bebida energética sabor manga, dizem eles. (GOTTFRIED, 2010, p. 29).

Como já citado, em seu estudo sobre o corpo e a cidade, Richard Sennett aponta para uma ausência de reação, o "apassivamento" do corpo dos habitantes das grandes cidades contemporâneas, com fortes semelhanças à atitude "impessoal" de seus habitantes definida por Georg Simmel como "atitude blasé", que consistiria no "embotamento do poder de discriminar", em uma equalização dos estímulos, e das respostas a eles. Tal comportamento seria fruto de um excesso de estímulos, aos quais é impossível reagir, porque "agita[m] os nervos até seu ponto de mais forte reatividade por um tempo tão longo que eles finalmente cessam completamente de reagir" (SIMMEL, 1979, p. 16). Nas cidades fragmentadas, onde grande parte da experiência é mediatizada pelos meios de comunicação, "experimentamos nossos corpos de uma maneira mais passiva do que o faziam as pessoas que temiam suas próprias sensações" (SENNETT, 1997, p. 17). O espaço que não se opõe à movimentação não causa, além do mais, experiências desconfortáveis, especialmente aquelas em que é preciso levar em consideração a existência de um outro, cujos interesses podem opor-se a nossos desejos de movimentação. Acreditamos que a opção por sabores cada vez mais intensos - que podem ser aproximados de filmes cada vez mais violentos, com um número crescente de explosões, ou comédias cada vez mais estupidificadas, que pouco apelam 
à capacidade interpretativa de seu público - associa-se à vida em espaços que não propiciam o encontro de sujeitos, espaços que podem ser atravessados sem percalços que gerem desconforto. Assim, também a experiência alimentar é sempre protegida do desconforto, pois ao consumirmos o produto com sabor de maçã elaborado por determinada empresa já sabemos a sua sensação, sem a surpresa de encontrar o que quer que seja numa fruta que acabou de ser mordida. Mas esse embotamento dos sentidos requer, também, sua contrapartida: a onda de sabores industrialmente mais ácidos, doces ou apimentados pode ser associada a um desejo de acumular experiências sensoriais, efetivamente, mas experiências essas que aconteçam em ambiente controlado, onde não se corre riscos - como são, aliás, os cinemas ou as casas de jogos de maior frequência. Tal relação com o próprio corpo, com as próprias sensações, é tributária da mudança nas configurações da experiência em nossos tempos, anunciada por Walter Benjamin no começo do século passado.

Abrir-se à experiência do novo - um novo cujas características não foram quase que completamente negociadas de antemão visando à satisfação garantida - aproxima-se do gesto criativo, que é sempre inaugural, não podendo ter sido, por isso, experimentado antes, mas tampouco encontra-se dissociado da tradição, representada pela experiência que se pretende transmitir. Esta, no entanto, deve ser o pavimento da construção de novas experiências - novas a cada novo gesto de (co)criação, prenhes do sentido de experiências transmitidas.

A experiência alimentar ilustrada pela reportagem que discutimos anteriormente se configura "inexpressiva, impenetrável, sempre a mesma" (BENJAMIN, 2002, p. 24). Ainda que a cada dia "novos" sabores sejam lançados, a experiência de prová-los é sempre a mesma, controlada, sem riscos. A partir dessa vivência não se cria nada de inusitado.

\section{A menina}

Um dos relatos da máquina de $A$ cidade ausente narra a história de uma menina que, buscando reservar "para si um território próprio [...] do qual quer excluir toda experiência" (PIGLIA, 1997, p. 46), acaba por excluir, também, a linguagem. A menina é diagnosticada por especialistas como sofrendo 
de "extravagâncias da referência", e sua perda da capacidade de usar corretamente a linguagem seria "conveniente à sua experiência emocional. Longe de não saber usar corretamente as palavras, via-se ali uma decisão espontânea de criar uma linguagem funcional à sua experiência de mundo" (PIGLIA, 1997, p. 45). Para a menina, "tudo o que for novo, qualquer acontecimento não vivido e ainda por viver surge [...] como uma ameaça e um sofrimento e se transforma em terror" (PIGLIA, 1997, p. 46).

A relação da menina com o mundo é, então, a da recusa à experiência de que falamos antes, e fecha-se, inclusive, para aquilo que denominamos "experiência domesticada". Não tem forças para criar relações efetivas seja com a palavra, seja com seus familiares ou consigo mesma; tal tarefa caberá a seu pai, dedicado a fazê-la entrar no mundo social da linguagem.

O pai passa, então, a narrar, como a máquina, através de versões de relatos, a mesma história que se multiplica e modifica em outras.

Esperava que as frases entrassem na memória de sua filha como blocos de sentido. Por isso resolveu contar sempre a mesma história e variar as versões. Desse modo o enredo era um modelo único do mundo e as frases se transformavam em modulações de uma experiência possível. O relato era simples. Em sua Chronicle of the Kings of England (século XII), William de Malmesbury relata a história de um jovem e potentado nobre romano que acaba de se casar. Após os festejos da celebração, o jovem e seus amigos saem para jogar bocha no jardim. Durante o jogo, o jovem coloca sua aliança, com medo de perdê-la, no dedo entreaberto de uma estátua de bronze que está junto à cerca dos fundos. Ao voltar para pegá-la, constata que o dedo da estátua está fechado e que não pode tirar o anel. Sem dizer nada a ninguém, volta ao anoitecer com tochas e criados e descobre que a estátua desapareceu. Esconde a verdade da recém-casada e nessa mesma noite, ao entrar na cama, percebe que algo se interpõe entre os dois, algo denso e nebuloso que impede que se abracem. Paralisado de terror, ouve uma voz que sussurra em seu ouvido:

- Abraça-me, hoje tu te uniste a mim em matrimônio. Sou Vênus e me entregaste o anel do amor (PIGLIA, 1997, p. 47).

É interessante destacar que a figura do anel está em todas as histórias contadas pelo pai, parecendo ecoar Walter 
Benjamin, para quem as palavras da experiência, em sociedades anteriores, eram "tão duráveis que [podiam] ser transmitidas como um anel, de geração em geração" (BENJAMIN, 1994a, p. 114). O anel, portanto, está ligado à tradição e à sabedoria ancestral que fazem parte do processo de transmissão da experiência. Também é anelar (circular) a organização da linguagem, que pressupõe, para cada ato enunciativo, um locutor $(e u)$ e um alocutário $(t u)$. Na fala, o locutor deve se apropriar da língua, "mas imediatamente, desde que ele se declara locutor e assume a língua, ele implanta o outro diante de si" (BENVENISTE, 1989, p. 84). No entanto, a fala não pede apenas que se "implante" um outro, mas sua própria constituição coloca o sujeito em relação a si mesmo, pois "o ato individual de apropriação da língua introduz aquele que fala em sua fala. [...] A presença do locutor em sua enunciação faz com que cada instância de discurso constitua um centro de referência interno" (BENVENISTE, 1989, p. 84). Desse modo, ganhar a língua não é apenas falar, mas também inserir-se nela como sujeito que fala.

Assim, sem constituir experiências com a linguagem, a menina não exclui apenas o outro, mas também a si mesma, de um relacionamento com o mundo, e suas "extravagâncias da referência" são, na verdade, uma forma de apagamento do endereçamento da linguagem, ou seja, um apagamento daquilo que possibilitaria sua relação com o mundo ao seu redor. "A menina não tinha referências", diz o narrador, "era como ensinar uma língua estrangeira a um morto. (Como ensinar uma língua morta a um estrangeiro)" (PIGLIA, 1997, p. 46-47). Estabelecer comparações entre sua posição perante a linguagem e a de alguém diante de uma língua morta é afirmar sua incapacidade de se situar como alguém que movimenta a língua, colocando-se nela como sujeito. Pois uma língua morta é aquela em que o testemunho é impossibilitado.

O contato entre o pai e a menina é mediatizado pelos relatos que este lhe conta. Não pode se comunicar diretamente com sua filha, mas através de textos - literários, no mais das vezes - pode chegar, como veremos, a tocar sua "terra-docoração". Podemos aproximar a prática do pai, que se coloca como narrador, transmitindo experiência, à do poeta, pois, diz Paul Celan, 
um poema, enquanto uma forma manifesta da linguagem e, portanto, intrinsecamente diálogo, pode ser uma mensagem em uma garrafa, lançada na crença (nem sempre muito esperançosa) de que ela poderá em algum lugar e em algum momento chegar à terra firme, talvez à terra-do-coração (apud FELMAN, 2000, p. 50).

Assim, a narrativa do pai é como uma mensagem na garrafa, como também o é, acreditamos, todo o processo de transmissão da experiência, que se dá sempre em um "entre", em que o saber é criado no ato mesmo de sua transmissão. Maria Rita Kehl nos diz que, no ato de narrar, aquilo que se viveu passa a constituir experiência, pois tal "endereçamento atesta a insuficiência do indivíduo ao mesmo tempo em que atualiza, e confirma, a insuficiência do Outro. O que se transmite é o que falha" (in COSTA, 2001, p. 22). Dessa forma, narrar não é exatamente compreender. O narrador não explica, e a experiência se constitui, também, nas lacunas de seu relato. É na falha, na cisão entre compreender e não compreender, entre saber e não saber, que se dá a narração. A experiência e a narrativa instauram-se nessa cisão, que se abre, necessariamente, para o outro. É preciso narrar porque não se tem todas as referências, porque não se tem o saber completo do vivido. Podemos recordar, agora, uma passagem de Isabel Quintana, que, analisando a experiência na obra de Piglia, afirma:

\begin{abstract}
A experiência, então, deveria pressupor o vazio como aquilo que não se pode jamais experimentar e que, ao mesmo tempo, constitui um novo tipo de vivência através de complexos processos narrativos nos quais a autorreflexão conduz a um transbordamento dos limites literários ao assinalar um fora em que habita o indizível (QUINTANA, 2001, p. 69).
\end{abstract}

Assim, é no momento em que se abre à sua falência, movimentando a língua para poder dizer $e u$, que a literatura, essa linguagem dos limites, pode constituir experiência.

Após escutar um grande número de versões do relato, a menina, enfim, conta sua versão ao pai, assumindo uma posição de sujeito: 


\begin{abstract}
"Mouvo olhou a noite. Onde tinha estado seu rosto apareceu um outro, o de Kenya. De novo o estranho sorriso. De repente Mouvo estava de um lado da casa e Kenya no jardim e os círculos sensoriais do anel eram muito tristes", disse. A partir daí, com o repertório de palavras que tinha aprendido e com a estrutura circular da história, foi construindo uma linguagem, uma série ininterrupta de frases que permitiram que se comunicasse com seu pai (PIGLIA, 1997, p. 48).
\end{abstract}

A linguagem da menina é, portanto, o que resta dos relatos. Quando a mensagem na garrafa, atirada pelo pai, atinge a sua "terra-do-coração", a menina toma a palavra. Poderíamos dizer que a palavra poética "age", dessa forma, restituindo a ligação com a vida, com a experiência. Em seguida, a menina pede um anel, inserindo-se, por fim, na relação social (dialógica) da linguagem e da experiência.

\title{
REFERÊNCIAS
}

AGAMBEN, Giorgio. Infância e História: destruição da experiência e origem da História. Trad. Henrique Burigo. Belo Horizonte: UFMG, 2005.

BENJAMIN, W. "Experiência e pobreza”. In: . Magia e técnica, arte e política. São Paulo: Brasiliense, 1994a, p. 114-119. BENJAMIN, W. "Experiência”. In: Reflexões sobre a criança, o brinquedo e a educação. São Paulo: Duas Cidades; Ed. 34, 2002, p. 18-29.

BENJAMIN, W. “O narrador”. In: . Magia e técnica, arte e política. São Paulo: Brasiliense, 1994b, p. 197-221.

BENJAMIN, W. "Sobre alguns temas em Baudelaire". In: . Charles Baudelaire um lírico no auge do capitalismo. Trad.

José Martins Barbosa e Hemerson Alves Baptista. São Paulo: Brasiliense, 1989.

BENVENISTE, Émile. Problemas de linguística geral II. Campinas, SP: Pontes, 1989.

COSTA, Ana. Corpo e escrita: relações entre memória e transmissão da experiência. Prefácio de Maria Rita Kehl. Rio de Janeiro: Relume Dumará, 2001. 
FELMAN, Shoshana. "Educação e crise, ou as vicissitudes do ensino". In: NESTROVSKI, Arthur; SELIGMANN-SILVA, Márcio (orgs.). Catástrofe e representação. São Paulo: Escuta, 2000. FOUCAULT, Michel. “O que é um autor?”. In: Estética: literatura e pintura, música e cinema (Ditos e escritos III). Rio de Janeiro: Forense Universitária, 2001.

GAGNEBIN, Jeane Marie. História e narração em Walter Benjamin. São Paulo: Perspectiva, 2009.

GAGNEBIN, Jeane Marie. Sete aulas sobre linguagem, memória e história. Rio de Janeiro: Imago, 1997.

GOMBATA, Marsílea. "Clicar, em vez de viver, tornou-se norma". Carta Capital online, 01 abril 2013. Disponível em http://www.cartacapital.com.br/cultura/clicar-em-vez-deviver-tornou-se-norma/. Acesso em 23 jul. 2014.

GOTTFRIED, Miriam. "Indústria turbina sabores para americanos". Jornal Valor Econômico, São Paulo, 01 jun. 2010, p. 29.

KEHL, Maria Rita. O tempo e o cão: a atualidade das depressões. São Paulo: Boitempo, 2009.

PARR, Martin. Too much photography. Disponível em http:// www.martinparr.com/2012/too-much-photography/. Acesso em 23 jul. 2014.

PIGLIA, Ricardo. A cidade ausente. Trad. Sérgio Molina. São Paulo: Iluminuras, 1997.

. "Prisão perpétua". In: Prisão perpétua. Trad. Sérgio Molina e Rubia Prates Goldoni. São Paulo: Iluminuras, 1989, p. 09-56.

QUINTANA, Isabel. Figuras de la experiência en el fin del siglo. Rosario: Beatriz Viterbo, 2001.

SENNETT, Richard. Carne e pedra: o corpo e a cidade na civilização ocidental. Trad. Marcos Aarão Reis. Rio de Janeiro: Record, 1997.

SIMMEL, Georg. "A metrópole e a vida mental". In: VELHO, Otávio Guilherme (org.). O fenômeno urbano. 4 ed. Rio de Janeiro: Zahar, 1979, p. 11-25. 


\section{Abstract \\ Language in circles: experience and narration in Ricardo Piglia}

One of the stories created by the narrative machine in the novel The absent city, by the Argentine writer Ricardo Piglia, presents the tale of a girl who, seeking to reserve "her own territory for herself [...] from which she wanted to delete experience as a whole", eventually eliminates language from her life. Thus, without constituting experiences with words, the girl not only erases the other, but also herself, from a relationship with the world. Since narrating is not exactly understanding, experience is constituted primarily in the gaps of what is reported. It is at fault, the division between knowing and not knowing, where one can encounter the narrative. Experience and narrative establish themselves in this gap, which opens necessarily to the other. From considerations on the transmission of experience in contemporary society, we analyze how, in Piglia's work, the relationship between language and experience takes place.

Keywords: Experience, Language, Ricardo Piglia. 